\title{
CORRIGENDUM
}

\section{RADIOCARBON DATING AT GRONINGEN: NEW AND UPDATED CHEMICAL PRETREATMENT PROCEDURES - CORRIGENDUM}

M W Dee $•$ S W L Palstra $•$ A Th Aerts-Bijma • M O Bleeker • S de Bruijn • F Ghebru • H G Jansen • M Kuitems • D Paul • R R Richie • J J Spriensma • A Scifo • D van Zonneveld • B M A A Verstappen-Dumoulin $\bullet$ P Wietzes-Land $\bullet$ H A J Meijer

DOI: 10.1017/RDC.2019.101, Published online by Cambridge University Press, 9 September 2019

In the original publication of this article, the chemical formula for sodium chlorite $\left(\mathrm{NaClO}_{2}\right)$ was presented incorrectly in three instances. The original article has been updated.

The authors apologize for this error.

\section{REFERENCE}

Dee MW, Palstra SWL, Aerts-Bijma AT, Bleeker MO, de Bruijn S, Ghebru F, Jansen HG, Kuitems M, Paul D, Richie RR, Spriensma JJ, Scifo A, van Zonneveld D, VerstappenDumoulin BMAA, Wietzes-Land P, Meijer

HAJ. 2019. Radiocarbon dating at Groningen: New and updated chemical pretreatment procedures. Radiocarbon:1-12. doi:10.1017/ RDC.2019.101 